\title{
Too Little Regulation? The British Market for Sherry, 1840-90
}

\author{
JAMES SIMPSON \\ Universidad Pablo de Olavide, Sevilla and Carlos III de Madrid
}

The regulation of markets for wine, beer and spirits by European governments in the nineteenth century was primarily concerned with revenue, with alcohol taxes in Britain for example accounting for approximately a third of government income. Governments attempted to maximise revenue by changing the nature of taxation or manipulating their rates, but they also found themselves obliged to take into account the costs that alcohol consumption imposed on third parties, especially intemperance, and the public health concerns associated with the sale of adulterated products. Taxation policy therefore fell not just on the drink itself, but also on the public premises where it was bought or consumed. Furthermore, because of social problems, including addiction, there was an obvious attraction for governments in creating new groups of consumers who would drink moderate quantities of relatively expensive beverages. Wine was often considered a luxury commodity in Britain during the first half of the nineteenth century, and consumption was limited because of high import duties. Gladstone in particular believed that significantly lower duties and changes in the retailing of wines would not only increase revenue, but would also provide consumers with more choice, and perhaps create a nation of wine drinkers. Duties in the early 1860s were cut, in some instances by over 80 per cent, and the retailing laws changed. However, although per capita consumption of all wines doubled in less than two decades, it proved only temporary, and by 1914 it had fallen to the same level as it had been in 1860 .

The subject of this essay shows the failure of one particular commodity, sherry, a quality wine produced in Jerez de la Frontera in southern Spain, to adapt to these new market opportunities. ${ }^{1}$ British imports, by far the most important of Jerez's markets, grew rapidly from the $1820 \mathrm{~s}$, and peaked in 1873 at eight million gallons, equivalent to 37 per cent of total consumption. However, by the end of the nineteenth century they had declined by three-quarters, and market share had fallen to little more than ten per cent. It is argued in this article that it was not the high level of duty importers had to pay which accounts for this failure, but rather that the new legislation to protect British consumers from adulterated products was insufficient to restore confidence in sherry once it had been lost. This difficulty might have been overcome if producers in Jerez had themselves created voluntary, self-regulating agreements, but this failed because of the diversity of interests in the sherry industry. It was not high taxation but rather the failure to protect the name of 'sherry' from the widespread availability of cheap imitations, often supposedly adulterated, which explains the slump in imports. 
The essay is divided into three parts. The next section considers briefly the debate over the level of wine duties, wine consumption and adulteration in the mid-nineteenth century. In the early 1860 s the government reduced duties significantly and made it easier for consumers to purchase wine, resulting in a doubling of per capita wine consumption in little more than a decade. However, lower wine prices were accompanied by increased concerns over adulteration and public health, which the Safe Food and Drugs Act (SFDA) of 1875 failed to fully resolve. The following section examines how producers along the commodity chain responded to the growth in demand. In Jerez, the shortage of quality wines caused by a series of poor harvests, produced a major short-term increase in prices. By contrast, the supply of cheaper wines was met by an extension in the area of cultivation to poorer soils, and mixing with wines from elsewhere. An important trade in 'artificial' sherries developed, sometimes using ingredients which were considered prejudicial to the consumer's health. The decline in quality of the cheaper sherries, and the concern of the widespread sale of adulterated wines, threatened the reputation of even the best sherries, encouraging consumers to turn to other wines and beverages.

The final section considers both the limitations of the 1875 SFDA legislation for the sherry trade, and the difficulties in introducing voluntary quality controls. Not only did domestic legislation concerning food adulteration fail to convince the British public that it was safe to drink sherry, but the British government was unwilling to recognise sherry as being exclusive to Jerez, and producers therefore had to compete with 'sherries' from other countries. However, perhaps the major reason for the decline in prosperity was the diversity of economic interests in Jerez itself that made the possibilities of selfenforcement of quality and establishing a common strategy to protect 'sherry' impossible. In particular, although Jerez's leading shippers sold quality wines under their own 'brand', they were also heavily involved in exporting large quantities of cheap wines produced from outside the region, which were often retailed in Britain as 'sherry'.

\section{II}

The British government received between 25 and 40 per cent of its revenue from taxes on alcohol during the nineteenth century. ${ }^{2}$ Therefore, although the social consequences of excess drinking and problems of addiction were a major concern of the Temperance movement and others, the fiscal importance of alcohol implied that the state was reluctant to restrict consumption. Not only did the government wish to protect this source of revenue, but it also was concerned that tax changes that encouraged the consumption of a particular beverage, such as sherry, might have a negative impact on the revenues collected from other drinks. However, wine differed from most alcoholic drinks in that it was imported. During the eighteenth and early nineteenth centuries the British discriminated between different trading partners, with Portuguese and Spanish producers paying lower duties than French. ${ }^{3}$ In 1825 tariffs were almost halved, but although producers of French wines paid $7 \mathrm{~s} 2 \frac{1}{2} \mathrm{~d}$ per gallon, those of all other wines paid only $4 \mathrm{~s}$ $9 \frac{3}{4} \mathrm{~d}$. From 1831 the bias against French wine was finally removed, and all wines were charged $5 \mathrm{~s} 6 \mathrm{~d}$ a gallon, but because Portuguese and Spanish wines were considered stronger than French wines, the latter continued to pay more in terms of duty per unit of alcohol. ${ }^{4}$ In the 1830s, Portuguese and Spanish wines accounted for approximately fourfifths of all imports, and French ones for just five per cent. 
Despite lower duties, consumption in the mid-nineteenth century was still limited to 'the finer kinds of wine, which are consequently within the reach of only the easy classes'. 5 The 1852 Parliamentary Commission, which was established to assess the impact of further reductions of duties, was divided in its opinions. Two concerns in particular stand out from the debate, namely the potential impact of lower duty on revenue, and whether producers could increase their supplies to meet a significant increase in British demand. They were in fact related. Sir James Tennent argued that because wine was a luxury, and demand therefore inelastic, revenue was likely to be maximised with high, and not low, duties. ${ }^{6}$ Furthermore, 'any great augmentation of the demand even for the lowest class of wines - the supply of which is assumed unlimited is pretty certain to be followed by a considerable enhancement of their costs at the places of their growth and shipment'?

In other words, the producer, and not the consumer, would enjoy the benefits from lower duties, and revenue for the Exchequer would consequently diminish. The debate was ended with the Anglo-French Treaty in 1860, when lower duties on wines were used as a bargaining tool to reduce French duties on a wide range of British industrial goods. ${ }^{8}$ By 1862, all wines entering British ports with an alcoholic strength of under 26 degrees proof (equivalent to 14.8 degrees Gay-Lussac) were taxed at a shilling a gallon, and above this level at $2 \mathrm{~s} 6 \mathrm{~d} .{ }^{9}$ Equally important was the new legislation on retailing that allowed wine to be sold in refreshment houses, and the 'single bottle' act, which created the off-licence for consumers to buy wine by the bottle to drink at home. ${ }^{10}$ Gladstone, as Chancellor of the Exchequer, firmly disagreed with Tennent, and believed that if duties were sufficiently reduced, consumption would increase 'enormously', and that an 'unbounded supply of wine' existed. ${ }^{11}$

Table 1 gives a rough idea of the potential impact of the changes of duties on wine prices in the $1850 \mathrm{~s}$ and $1860 \mathrm{~s}$. Before the tariff reforms in the early $1860 \mathrm{~s}$, duty accounted for half the retail price of ordinary table wines, and about a third on 'good' sherry, so it was the cheap, low-alcohol wines that benefited most from the reductions. ${ }^{12}$ If the supply of all types of wines had been perfectly elastic, then the new tariffs would have involved price cuts at the retail level of up to 70 per cent. However in the short run at least this was not the case. In particular, and as we shall see, the presence of oidium in European vineyards in the mid-1850s severely reduced the stocks of quality, matured wines just as the new tariffs were coming into operation. By contrast, and as shown in Figure 1, which is based on English wine prices, the new duties led to a fall in prices for the cheapest sherries. This suggests, as Gladstone had anticipated, that merchants were able to expand the supply of cheaper wines quickly so that it was the consumers who benefited from the reductions in duty, rather than the producers. Total wine consumption increased by 140 per cent between 1856/60 and 1871/75, with imports from France growing almost sixfold. Spanish wines, consisting mainly of sherry at this date, increased at roughly the same rate as the general market, so market share remained stable at 40 per cent. By contrast, wines from Portugal increased by a relatively modest two-thirds, and imports from other countries by a quarter.

This growth in consumption, together with the changes in the organisation of the domestic retail market, and the high prices of better sherries, led to complaints of sharp practices by dealers, and the sale of poor quality, and sometimes adulterated wines. In the first half of the nineteenth century, wine was often sold in barrels to private consumers, 
TABLE 1

IMPACT OF DUTIES ON RETAIL WINE PRICES IN THE UNITED KINGDOM, 1850S AND 1860S

\begin{tabular}{|c|c|c|c|c|c|c|}
\hline \multicolumn{7}{|c|}{ Tariff Levels 5s 9d a gallon. In use between 1840 and 1859} \\
\hline & London & & $50 \%$ Retailer & & Price per & Duty as $\%$ of \\
\hline & Import Price & Duty & Mark-Up & Total & Bottle & Retail Price \\
\hline 'Good' Sherry & $£ 28$ & $£ 313 \mathrm{~s}$ & $£ 2411 \mathrm{~s}$ & $£ 8914$ s & $2 \mathrm{~s} 9 \mathrm{~d}$ & 35 \\
\hline 'Tavern' & $£ 14$ & $£ 313 \mathrm{~s}$ & $£ 2211 \mathrm{~s}$ & $£ 6714 \mathrm{~s}$ & $2 \mathrm{~s} 1 \mathrm{~d}$ & 46 \\
\hline \multicolumn{7}{|l|}{ Sherry } \\
\hline Table Wine & $£ 6$ & $£ 313 \mathrm{~s}$ & $£ 1811 \mathrm{~s}$ & $£ 5514 \mathrm{~s}$ & $1 \mathrm{~s} 9 \mathrm{~d}$ & 56 \\
\hline \multicolumn{7}{|c|}{$\begin{array}{c}\text { Tariffs: Less than } 26 \text { degrees, } 1 \text { s per gallon and less than } 42 \text { degrees, } 2 \text { s } 6 \mathrm{~d} \text { a gallon. } \\
\text { In use between } 1862 \text { and } 1886 .\end{array}$} \\
\hline 'Good' Sherry & $£ 28$ & $£ 13.10 \mathrm{~s}$ & $£ 2015 \mathrm{~s}$ & $£ 625 \mathrm{~s}$ & 1s 11d & 22 \\
\hline 'Tavern' & $£ 14$ & $£ 1310$ s & $£ 1315 \mathrm{~s}$ & $£ 415 \mathrm{~s}$ & $1 \mathrm{~s} 3 \mathrm{~d}$ & 33 \\
\hline Sherry & & & & & & \\
\hline Table Wine & $£ 6$ & $£ 54 \mathrm{~s}$ & $£ 512 \mathrm{~s}$ & $£ 1616 \mathrm{~s}$ & $6 \mathrm{~d}$ & 31 \\
\hline
\end{tabular}

Note: Calculations have used a sherry butt of 108 gallons, with one gallon taken as six bottles. Sherry is assumed to have an alcoholic strength of between 26 and 42 degrees proof, table wines less than 26 degrees. Figures are rounded.

Source: Based on Dover, in Parliamentary Papers (1852, xvii) Report from the Select Committee on Import Duties on Wines, p.653.

FIGURE 1

SHERRY PRICES IN LONDON, DUTY PAID

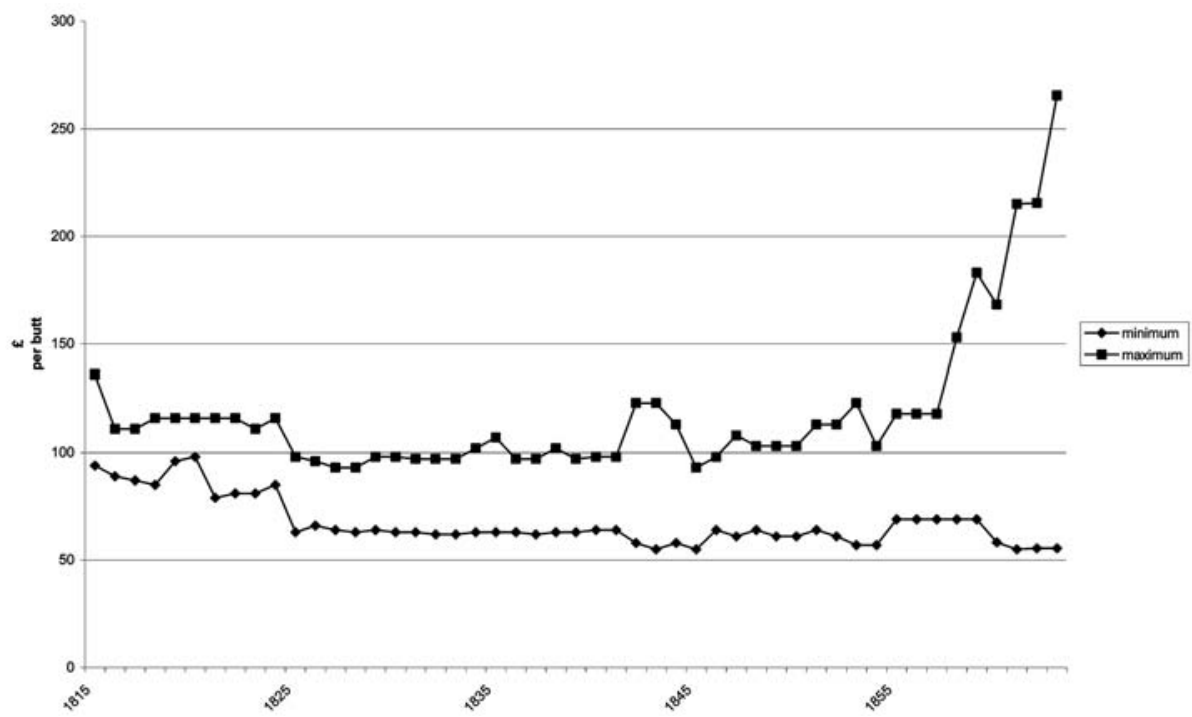

Sources: G.M. Gonzalez, Sherry: The Noble Wine (London, 1972); T.W. Shaw, Wine, the Vine and the Cellar (London, 2nd edn. 1864), p.235.

who bottled it themselves. The traditional British wine merchants established their reputation as intermediaries because they dealt with a limited number of buyers of high priced wines, and repeat purchases were expected. Because consumers often came from similar geographical and social backgrounds, short-term opportunistic behaviour by a 
wine merchant selling poor wine at inflated prices to one consumer was likely to be known quickly to others. By contrast, for the tavern trade, wine was often bought on the open market and, because the business of both wine merchants and publicans required the mixing of wines, or their strengthening with alcohol to preserve them, the possibilities of adulteration by dishonest individuals was considerable. ${ }^{13}$ Cyrus Redding, writing in the early 1830 s, noted that sherry was sometimes mixed with cheap wines to create 'inferior sherries', and then strengthened with brandy before being exported, but they were never adulterated in Spain. ${ }^{14}$ By contrast, in England, 'Sherry of the brown kind, and of low price, when imported is mingled with Cape wine and cheap brandy, the washings of brandy casks, sugar candy, bitter almonds, and similar preparations, while the colour, if too great for pale sherries, is taken out by the addition of a small quantities of lamb's blood, and then passed off for the best sherry by one of wine sellers and advertisers'. ${ }^{15}$ The publication of Dr Arthur Hassall's scientific work in the Lancet between 1851 and 1854 showed the public both the extent of food adulteration at this time, and its implications for public health. ${ }^{16}$ Whether this was actually greater at this date compared to earlier periods is impossible to determine, but the increasing importance of national and local newspapers resulted in wider public awareness, and the demand for regulatory action by local and national authorities. With the Sale of Food and Drugs Act of 1875, which defined adulteration in terms of risk to the consumer's health, or deception concerning the description of the product, the beginnings of an effective legal framework to combat fraud was established. ${ }^{17}$ This placed the regulatory emphasis on the retailer rather than producer, and allowed the sale of 'compound foods', provided that these were neither dangerous and were adequately labelled. ${ }^{18}$

As we shall see, this regulation by the state to protect British consumers had its limitations. Just how much adulterated sherry was being sold when the Sale of Food and Drugs Act of 1875 was approved is impossible to know. Furthermore, although Henry Bartlett, a Fellow of the Chemical Society, believed, as Cyrus Redding had earlier, that most adulteration took place in England and not in Spain, others were less convinced. ${ }^{19}$ However, and as we shall now consider, the worry that large quantities of sherry were possibly dangerous to the drinker's health, together with the difficulties in providing consumers with accurate information concerning the wine's quality, seriously damaged the drink's reputation in the British market, and caused the decline in sales.

\section{III}

As sherry and port accounted for approximately three-quarters of British imports in the 1850 s, wine merchants naturally looked first to these regions for sources of cheap wines after 1860. Indeed, it was noted that 'with regard to white wines suitable for British requirements, we have at present seen nothing capable of competing successfully against Sherry: French productions, except at very high rates, are for the most part of a very indifferent quality, and, unless fortified up to 30 per cent, will not be safe as regards keeping properties'. ${ }^{20}$

By the 1860 s there were perhaps 8,500 hectares of vines in Jerez itself, an increase of several thousand from earlier in the century. ${ }^{21}$ Quality wines in southern Spain were produced almost exclusively for the export market, with Britain accounting for 87 per cent of the total at the height of sherry's prosperity between 1861 and $1865 .^{22}$ Although 
figures on output are scarce, the long-run trends in exports (Table 2) and prices (Figure 2) help indicate the changes in prosperity. Exports to all markets, for example, rose from an annual average of less than ten million litres in the 1820 s, to almost 40 million in the early 1870s. At the same time, the price of must in Jerez tripled between 1850/53 and $1860 / 63$. This was not caused so much by normal supplies being inadequate for the increased demand, as Tennent and others had feared, but rather because of a new vine disease, which devastated local harvests. Between 1853 and 1856 harvests fell from about 60-70,000 butts, valued at $£ 7$ each, to $18-20,000$ butts, which were sold for between $£ 16$ and $£ 20$ each. Even so quality was only regular, and in 1860 it was noted that because sherry was 'never exported under three or four years', exports since 1855 had been 'supplied from the large stocks on hand, and not by late vintages'. ${ }^{23}$ There was therefore a sharp drop in the supply of quality sherry just as duties were cut in Britain, leading to considerable prosperity in Jerez, rather than benefiting consumers in England. It did not last, and prices fell quickly after 1863 , when the post-oidium wines became sufficiently mature to export.

Jerez was traditionally a high-cost wine-producing region because of the low yields, high labour requirements and taxation. ${ }^{24}$ The sharp cuts in duty after 1860 also encouraged the export of cheap, young wines from outside Jerez. This process was helped by the opening of new railways, and especially the direct link between Madrid and Jerez, which was completed in 1866. The cost of transportation between the white wine producing region of Montilla in Cordoba and Jerez, for example, which had previously

TABLE 2

TRADE IN SHERRY AND SPANISH WHITE WINE

\begin{tabular}{|c|c|c|c|}
\hline & \multirow{2}{*}{$\begin{array}{c}\text { Exports of Sherry from Jerez } \\
\text { and Puerto Santa } \\
\text { María*, in millions } \\
\text { of litres }\end{array}$} & \multicolumn{2}{|c|}{ Imports of 'Spanish White' into the United Kingdom } \\
\hline & & $\begin{array}{l}\text { Total Imports, in millions } \\
\text { of litres }\end{array}$ & $\begin{array}{c}\text { 'Spanish White', as \% of } \\
\text { Total Imports }\end{array}$ \\
\hline $1821-25$ & $5.75(1821-22)$ & 6.67 & 20.5 \\
\hline $1826-30$ & 10.15 & 10.18 & 28.2 \\
\hline $1831-35$ & 13.20 & 11.15 & 31.1 \\
\hline $1836-40$ & 15.92 & 13.36 & 32.5 \\
\hline $1841-45$ & 15.04 & 11.83 & 33.6 \\
\hline $1846-50$ & 17.82 & 12.54 & 34.1 \\
\hline $1851-55$ & 22.54 & 14.72 & 34.7 \\
\hline $1856-60$ & 23.26 & 15.34 & 36.5 \\
\hline $1861-65$ & 28.62 & 23.21 & 38.2 \\
\hline $1866-70$ & 33.71 & 27.66 & 30.9 \\
\hline $1871-75$ & 39.53 & 29.69 & 33.9 \\
\hline $1876-80$ & 27.35 & 21.62 & 26.9 \\
\hline $1881-85$ & 25.09 & 15.19 & 21.6 \\
\hline $1886-90$ & 24.17 & 12.15 & 17.4 \\
\hline $1891-95$ & 17.27 & 9.88 & 13.8 \\
\hline
\end{tabular}

Notes: * Exports to all countries, not just Britain.

Sources: Exports: J. Maldonado, La formación del capitalismo en el marco del Jerez (Madrid, 1999), p.312 and E. Montañés, La empresa exportadora del Jerez: Historia económica de González Byass, 1835-1885 (Cádiz, 2000), pp.253-4. Imports: G.B. Wilson, Alcohol and the Nation (London, 1940) and Ridley's, various years. Prior to 1868 it has been assumed that white wines were equivalent to 84 per cent of total Spanish imports. 
FIGURE 2

PRICE OF MUST IN JEREZ

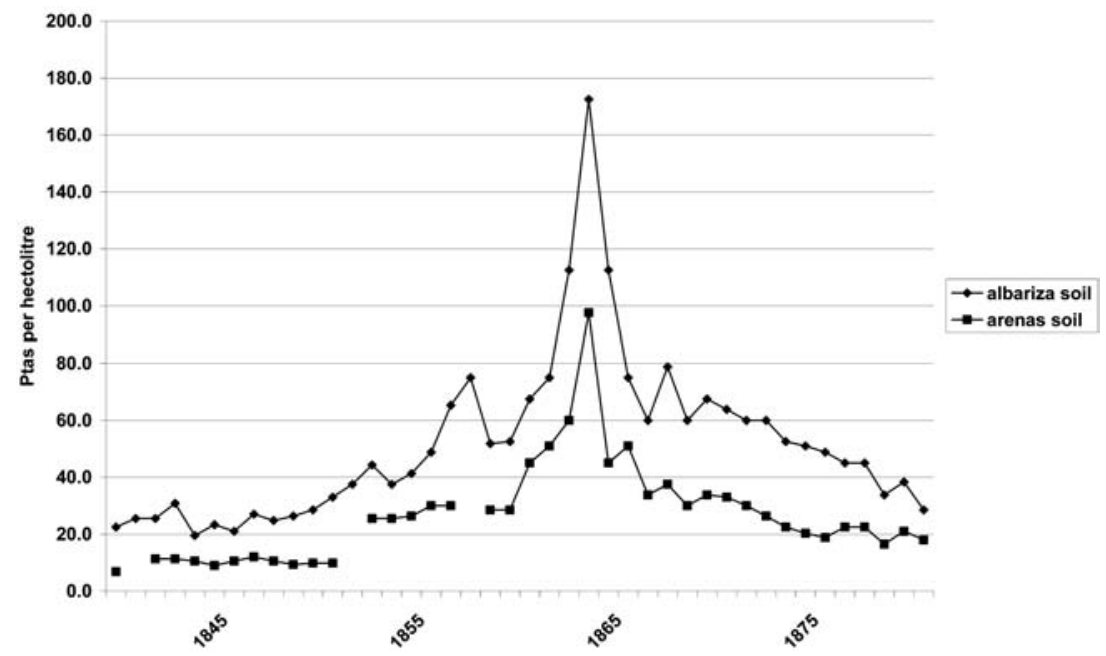

Sources: G.M. Gonzalez, Sherry: The Noble Wine (London, 1972); T.W. Shaw, Wine, the Vine and the Cellar (London, 2nd edn. 1864), p.235.

been $£ 8$ per barrel, was cut to $£ 2$, encouraging the exporter González Byass to established wine-making facilities in that city. ${ }^{25}$ If quality wine was limited to the better vineyards of Jerez, Montilla and Sanlucar, large quantities of cheap, inferior wines were to be found elsewhere in Andalucía and La Mancha. These inferior wines were at first mixed with sherry, but increasingly were exported after only a few months through Jerez's commercial networks, sometimes as 'sherry'. Ridley's Wine and Spirit Trade Circular responded to this change by adding prices for a sixth wine to its list - 'Sound Cadiz White Wine' - which sold at between $£ 14$ and $£ 16$, compared to the five traditional qualities of sherry which ranged from $£ 22$ to $£ 250$ a butt. ${ }^{26}$ Ridley's also increasingly spoke of 'Spanish white wines', rather than 'sherry'. Therefore, if the shortage of quality wine pushed prices to spectacular heights in the early 1860s, the more elastic supplies of cheap white wines from regions surrounding Jerez kept the price for the cheapest 'sherry' stable in London (Figure 1). In years of shortage, shippers reduced the quality of these wines, rather than increasing prices. ${ }^{27}$

It was perhaps not surprising that, if the Jerez shippers sold wines from other regions of Spain as sherry, shippers from elsewhere would also try to imitate it. In 1863 a group of 29 exporters from Jerez gave Ridley's a gift of $£ 100$ for 'discovering, exposing, and frustrating traffic in spurious Wines' - wine that had been shipped from London to Cadiz, and returned as 'Sherry'. ${ }^{28}$ More serious for shippers, and the health authorities in Britain, was the production of imitation sherries which had no links to wine producing regions. Industrial alcohol made from substances such as sugar beet and potatoes was very cheap, and used as a base for the 'manufacture' of wines, the most notorious perhaps being the 'Hamburg' sherries. This wine, according to the Medical Times and Gazette, 
was 'in its original state ... a light German wine of poor quality, not possessing in that condition sufficient preserving powers to render it suitable for shipment, or indeed for consumption as a natural wine in its country'. ${ }^{29}$ An attempt was made to overcome these defects by adding spirit and saccharine. One recipe for 'Elbe' sherry is given in Table 3, but, as the author noted, the return of capital of around 13 per cent could be considerably increased if more water, and less wine, was added.

Although from 1865 this type of wine was prohibited from entering the United Kingdom for reasons of public health, it is clear that similar wines did. ${ }^{30}$ Indeed, the leading retailer Gilbey's, which was responsible for five per cent of all wine sold in the United Kingdom in 1875, only dropped 'Castle Hambro Sherries' from its lists in 1877. ${ }^{31}$ As one senior partner noted, 'for some years past we felt that we could not give that assurance of their genuiness [sic] as wine as we wished to do, and we decided some years ago not to ship them. In fact, we thought that they rather interfered with the status of our business generally'. ${ }^{32}$ The reputation of sherry had been damaged much earlier, as Shaw observed in his important book in 1863: 'Sherry has long been the favourite wine, but the quantity of bad quality now shipped and sold under its name has already injured its reputation; while the high prices of any that is good and old offer an opening for the introduction of another white kind'. 33

One of the reasons why adulteration was relatively easy was because of the high alcoholic content of sherry. Contemporaries were often impressed by the young, nonfortified wines of the Jerez region, but virtually none were exported. ${ }^{34}$ Spirits were added to stabilise the wine, to prevent disease and stop it turning sour with travel. Fortification therefore took place, not because it was 'what is wanted in England, but rather the demand is for cheap wines, and this is the only way to obtain them'. ${ }^{35}$ From the late 1870 s the price of cheap wines everywhere in Europe increased significantly because of another vine disease, phylloxera, and sherry exporters frequently used the cheaper industrial alcohol to fortify their less expensive wines to remain competitive. The extent to which these were prejudicial to health is difficult to assess, but the public concern hastened the decline in popularity of the drink. ${ }^{36}$ By contrast, the better sherries, when properly matured, required less alcohol than those which were exported after only a few months.

TABLE 3

PRODUCTION COSTS OF 'ELBE' SHERRY

\begin{tabular}{lcc}
\hline Cost Item & Quantity & Costs \\
\hline Proof Potato Spirit & 40 gallons @ 1s 4d & $£ 213 \mathrm{~s} 6 \mathrm{~d}$ \\
Water & 56 gallons & \\
Capillaire & 4 gallons @ $5 \mathrm{~s}$ & $£ 2$ \\
Wine & 10 gallons @ 4s & $12 \mathrm{~s}$ \\
Cask & & $10 \mathrm{~s}$ \\
Labour \& Shipping & & $2 \mathrm{~s} 6 \mathrm{~d}$ \\
Commission & & $4 \mathrm{~s}$ \\
Discount for cash & $£ 72 \mathrm{~s}$ \\
Total & & $£ 8$ \\
Wholesale Price & & \\
\hline
\end{tabular}

Source: Ridley's (7 Jan. 1864), p.5 and text. 
As can be seen in Table 2, imports of sherry declined rapidly from the late 1870s, and market share was lost. In Jerez it was widely believed that a major cause of this decline was the higher duty that their wines had to pay because of their greater strength compared to French wines, and sherry shippers launched a publicity campaign to reduce them. ${ }^{37}$ But the British authorities were not convinced, and there was opposition from part of the domestic wine trade. As the shipper A.G. Sandeman noted,

in the wine trade there are a great many conflicting interests. You have the merchants connected with Spain and Portugal who wish to have their strong wines introduced on the most favourable terms. You have the dealers in light wines who wish to have a monopoly, as it were, and have the duty kept high on the strong wines ... Then you have those connected with the spirit trade who look with great jealousy upon a reduction of the duty upon strong wines as likely to affect their interests; so that really it is most difficult to reconcile every interest in the trade. ${ }^{38}$

It was also argued that a reduction in duty from a $2 \mathrm{~s} 6 \mathrm{~d}$ to a shilling a gallon would have only a marginal impact on retail prices, and there was no guarantee that it would be passed on to the consumer. ${ }^{39}$ The British authorities were concerned primarily with the implications on revenue. A too-liberal duty, such as extending the duty of a shilling a gallon to all wines under 42 degrees (rather than just 26 degrees), risked encouraging an increase in consumption of strong wines at the expense of spirits. It was pointed out that in terms of alcoholic content spirits were already the heaviest taxed, followed by wine and then beer. Indeed, some, including the Inland Revenue, feared that lower duties would result in strong wines being imported to be illegally distilled, even though cheaper alternatives, such as alcohol produced from maize, oats, sugar and other products, existed. $^{40}$

The duty on imported wines was finally changed in 1886 , when the shilling duty was extended to wines of between 27 and 30 degrees. As Table 4 shows, by the early 1890 s almost two-thirds of Spanish wines paid the lower duty, although by this date not only had imports declined, but red wines, mainly from Tarragona, now accounted for 70 per cent of the Spanish total. The fact that sherry exports did not recover with the lower duties after 1886 can partly be explained once more by adulteration. In their attempts to reduce the alcoholic content of the cheaper sherries to under 27 degrees, some producers

TABLE 4

ALCOHOLIC STRENGTH OF WINE IMPORTS INTO THE UNITED KINGDOM (\% of total)

\begin{tabular}{lccc}
\hline & $\begin{array}{c}\text { Wine Imports of } 26^{\circ} \text { Proof } \\
\text { or Less in } 1875\end{array}$ & $\begin{array}{c}\text { Wine Imports of 26 } \\
\text { or Less in } 1882\end{array}$ & $\begin{array}{c}\text { Wine Imports of } 30^{\circ} \text { Proof } \\
\text { or Less in } 1893\end{array}$ \\
\hline Spain & 3.0 & 10.7 & 62.7 \\
Portugal & 1.6 & 1.7 & 3.9 \\
France & 91.7 & 99.0 & 99.8 \\
Other Countries & 16.9 & 25.1 & 81.1 \\
Total & 24.2 & 35.3 & 61.6 \\
\hline
\end{tabular}

Sources: Parliamentary Papers, Report from the Select Committee on Wine Duties (1878/79, xiv), pp.315-17; Ridley's (Aug. 1883), p.241 and (June 1894), p.361. 
reportedly used German spirits and salicylic acid as cheap preservatives, which were both illegal and in some cases prejudicial to public health. ${ }^{41}$ Although perhaps the number of cases was small, it reinforced once more the notion that cheap sherries were dangerous.

The poor quality of many of the cheaper sherries, and the concern of the widespread sale of adulterated wines, also threatened the reputation of good sherry. For most wines, quality was determined by where it was produced (location of the vineyard) and the quality of the year's vintage. In the case of claret, the ranking of the leading growers with the Bordeaux Classification of 1855, and estate bottling after good harvests, provided consumers with relatively accurate information. Champagne and port was sold in bottles under the brand of the manufacturers, with the best also being sold as 'vintage'. This was not the case with sherry. Sherry is very rarely sold according to its vintage, because it is a blended wine. Virtually all quality sherry was produced using the solera system, which consists of wines of a similar type, but of different stages of development, stored in large casks. As one nineteenth-century visitor noted, 'what is withdrawn from the oldest and finest casks is made up from the cask [sic], which approach them nearest in age and quality, and these are again replenished from the next in age and quality to them. Thus, a cask of wine, said to be fifty years old, may contain a portion of the vintages of thirty or forty seasons'. ${ }^{42}$ If only small quantities of wine are removed, the new wine assumes the characteristics of the older one in a few months. ${ }^{43}$ The solera not only helped produce wines of similar characterises, it reduced the time that they had to be matured. However, if efficient in reducing production costs, the solera perhaps made it harder to market the better quality wines. As Ridley's noted, the public perhaps could understand the terminology of 'vintages' and 'growth' associated with champagne, port or clarets, but were much more confused by 'vague names such as Vino de Pasto, Amontillado, Oloroso, etc; the result is that he has less means of judging what price he ought to pay'. ${ }^{44}$ This failure to adapt to the more impersonal markets of the late nineteenth century, and the inability of the legislation in Britain to reduce the threat of adulteration, implies that we need to consider more closely shippers' polices in Jerez, and the difficulties in developing self-enforcement mechanisms to control quality.

\section{IV}

The growth in demand for sherry, and the shortage of supplies caused by oidium, created a boom in the Jerez region that reached its peak in the mid-1860s. Not only were business fortunes made, but also the attempts to increase local output led to labour shortages and local wages doubled from the early 1850 s to the early 1860 s. ${ }^{45}$ It did not last. With the collapse in prices and exports, there followed a succession of business closures, cuts in real wages, unemployment and falling population. The city and its hinterland became a centre for anarchism, and social unrest was widespread during the late nineteenth century. ${ }^{46}$ Although the declining fortunes of the sherry trade were not the only factors to explain this, they were arguably the most important, and it therefore needs to be asked why those involved in the sherry trade were unable to halt its decline.

By the mid-1860s the problems of imitation sherries in the British market were only too apparent, as prices fell sharply. Three major types of imitation can be distinguished. First, wines purchased by exporters from outside the Jerez region, which were then mixed with local wines or simply shipped as sherry. Second, the production of 'sherry' in 
countries such as South Africa, which was then marketed in Britain at lower prices than Jerez sherry. Finally, the 'manufacture' of sherry using ingredients other than just wine, which on occasions was detrimental to health. All helped to depress prices in London for the real drink. As we shall now argue, the diversity of interests in Jerez itself explains best the limited action to protect the name 'sherry'.

Regulation in the British market through the SFDA was limited to the areas of public health and fraudulent labelling. As the British authorities considered sherry a generic name for a particular type of wine which was not limited to the Jerez district or even to Spain, 'Cyprus sherry' or 'Cape sherry' were judged as legitimate as 'Spanish sherry'. This was unfortunate for the sherry business, but in fact typical of the European wine market at this time. Producers everywhere tried to imitate popular wines, and Spanish merchants were also quite happy to sell imitation ports or clarets in their own market, and elsewhere when possible. Therefore regulation in Britain was limited to protecting consumers against products considered dangerous to the public health, and the individual brands of the shippers or growers that had been infringed.

A more promising area for regulation lay with the producer, rather than the consumer. Regulation might have taken the form of establishing a geographical area outside of which sherry could not be produced. Throughout Europe during the ancien régime there had been a tradition of 'protecting' local wines from those produced elsewhere. Municipal regulations often required that wines produced outside the municipality could not be sold before a particular date, thereby giving local wines a temporary monopoly. ${ }^{47}$ Once prices started falling from the mid-1860s, there was widespread demand in Jerez that only local wines should be exported as sherry, or local taxes should be raised sufficiently to make the sale of outside wines unprofitable. However, no legislation of any importance was introduced.

The problems facing Jerez's sherry producers were hardly unique. In the region of Oporto, the controversial Companhia Geral de Agricultura das Vinhas do Alto Douro was established as early as 1756 and, amongst other things, controlled wine production and the quality of port which was exported. ${ }^{48}$ Elsewhere, when a period of high prices was brought to an end because cheaper wines were being sold as the genuine product, there were similar demands for regulation. The first attempt in France was the 1905 legislation, which began the process of establishing regional denominations for a number of wines, including 'Bordeaux' and 'Champagne'. The difficulties in satisfactorily defining geographical boundaries became quickly apparent, with conflicts arising over which municipalities should be included or excluded. In Bordeaux, for example, the easy political decision was taken of allowing only wines from the Gironde to use the denomination 'Bordeaux', but in the Champagne region the major vineyards were spread over several départements, and the issue led to serious political unrest in $1911 .^{49}$ Because of the widespread blending of different types of wines in both regions, a relatively large section of the merchant community was opposed to any legislation that restricted these activities. Legislation was only passed because of the relative strength of the growers, and the interests of some of the leading merchants in protecting the reputation of quality wines.

In Jerez, local growers and the wine maturers (almacenistas) lobbied for similar restrictions from the mid-1860s, and at times threatened shippers who bought wines from outside the region with physical violence. ${ }^{50}$ Another complaint was the importation of German industrial alcohol which was used for strengthening sherry, and which made it 
unprofitable to distil local wines after poor harvests. Although tariffs were significantly raised on this item in 1890, wine growers and almacenistas were unsuccessful in introducing a regional denomination for Jerez.

Unlike the production of grapes and the maturing of wine, the export trade was concentrated in the hands of a few companies. Between 1852 and 1865, for example, the houses of Garvey, Domecq and González accounted for a third of all exports from Jerez, and the leading five houses rarely exported less than half of all the sherry. As in the claret and port trade, the reputation of a shipper helped reduce problems of asymmetric information. Reputation was achieved by shared values and beliefs with leading British importers, often reinforced by exclusive contracts and sometimes intermarriage. ${ }^{51}$ However, by selling large volumes of cheap wines after 1863, often without their brands, exporters were able to partly offset the impact of declining wine prices. ${ }^{52}$ There was in fact a positive incentive to do this, because of the widespread publicity given to the annual shipping lists, which ranked shippers according to the volume of exports regardless of quality. ${ }^{53}$

Unlike the leading champagne houses, which had a thriving market for their quality wines, sherry houses were increasingly trying to compete on cost rather than quality by the late nineteenth century. ${ }^{54}$ Therefore, the Asociación Gremial de Exportadores, the shippers' pressure group, which was founded in 1910, argued that sherry was a generic name, and to compete with foreign 'sherries' it was necessary to mix Jerez's wines with cheaper ones from elsewhere. ${ }^{55}$ When a controlled appellation was established in $1935-$ the Consejo Regulador de la denominación de origen Jerez-Xérès-Sherry - the interests of the shippers in acquiring cheap wines was respected. ${ }^{56}$ If exporters had been successful by the late nineteenth century at manufacturing a wide range of different wines to be sold as sherry, this had come at the expense of sherry losing its identity with the Jerez region for the consumer.

If there was only a weak response at attempting to find a collective solution, individual shippers tried to reduce the adulteration of their wines by creating their own brands. The technologies that had encouraged food adulteration in the first place, especially falling transport, were also central to the 'retailing revolution', and the appearance of multiple stores, advertising and branding. Branding in particular might help to reduce communication costs by differentiating products, assuring minimum quality standards, and strengthening shippers' reputation. ${ }^{57}$ As we have noted, there were very few 'vintage' wines, because it was the blending of wines from different years that gave sherry its distinctive flavour. However, the solera system did allow the shippers to keep wine quality constant from one year to the next, which helped to develop brands. González Byass, for example, had a number of old soleras such as Matusalén, Apóstoles or Tio Pepe, expensive wines which sold in the late 1870 s for 5 s or more a bottle, about five times the price of 'cheap' sherries. ${ }^{58}$ In England, the importers Harvey's of Bristol sold its Bristol Cream from 1882, if not earlier, but again this was an expensive sherry. ${ }^{59}$ Because of their relatively high cost, these wines were more likely to be sold through traditional distribution channels of wine merchants, rather than by grocers who owned an off-licence.

An alternative approach might have been for the Spanish government or Jerez authorities to have promoted sherry more. Indeed, the main concern of Ridley's wine journal was the lack of response from Jerez's shippers in defending sherry from its detractors, and it criticised the shipper Cosens in particular for spending too much time 
lobbying to reduce import duties in the belief that this would increase sales. ${ }^{60}$ The problems concerned not just cheap sherries, because the accusation made in 1873 by Dr Thudichum argued that there were health implications from drinking even good quality sherry because of the use of gypsum in the crushing of the grapes, and sulphur in the fumigation of the casks. ${ }^{61}$ In 1879, Robert Houldsworth, a partner in Gonzalez, Byass \& Co. complained that doctors, 'a very powerful section of the community, ... have been running down sherry lately'. ${ }^{6}$ They were not alone, as Thudichum's claims were 'disseminated throughout the length and breadth of the land by a local Press ever hungry for copy and not too careful either as to its accuracy or the mischief that would naturally accrue from its publication. Thus it has happened that, outside the Trade Papers themselves, little or nothing has been published to disabuse the public mind of the wrong impressions under which it labours as to the supposed unwholesome character of Sherry'. ${ }^{63}$

Sherry producers and shippers did little to try and convince consumers that the drink was actually safe. Indeed, the task of showing that Thudichum was wrong was left to the regulatory authorities in Britain and the Lancet, rather than the activities of Spanish merchants. It took, however, 20 years before the report appeared.

The example of sherry is not that of exporters failing to break into the rich urban markets of northern Europe, but rather their failure to maintain these markets once they were gained. In this respect, the arguments that were often advanced by contemporaries, and some historians, that the major problem was the level of tariffs appears incorrect. Tariffs ranged from less than four per cent of the retail price of the relatively expensive sherry, Tio Pepe, in the late 1870 s, to about 25 per cent for cheap sherries. The real problem was that sherry was expensive to produce, and therefore it had difficulties competing on price without being mixed with wines from other regions. A second problem, that of asymmetrical information, made it difficult for consumers to recognise quality sherries unless they bought their wines from a reputable merchant.

The 1875 SFDA, by regulating at the point of sale, rather than manufacture, encouraged retailers to sell mass-produced and branded products, or those commodities where they could control the quality. Although potential adulteration was a common problem with all wines in the late nineteenth century, sherry suffered more than most, in part because it was a fortified wine (as port), which made it easier to disguise changes. However, if the SFDA helped remove the worse abuses of adulteration, there were naturally many disputes over what constituted a health hazard. As we have seen, even the best wines suffered because of the adverse publicity that surrounded the use of gypsum and sulphur in their production. Thudichum was wrong, but consumers in Britain were only provided with the scientific evidence a couple of decades later.

In the meantime, these problems were fully exploited in the press by the drink's opponents. These included not only increasingly the medical profession, but also the Temperance movement, which objected to the higher strength of the sherry compared to other wines. Furthermore, a number of wine merchants and writers who wished to promote other wines, such as James Denman, were also quick to criticise sherry. ${ }^{64}$ Another problem was that the constant manipulations of wines in Jerez and other 
countries left consumers without a clear idea of the nature of the real product. Indeed, when the debate concerning the establishment of a controlled appellation began, shippers insisted that the region's prosperity was based as much on its ability to manufacture wines, many coming from other regions, as those wines from the immediate locality of Jerez.

It seems apparent that the decline in sales of sherry from the early 1870 s can be attributable to a decline in confidence in the drink, encouraging consumers to turn to other wines which they believed safer. Informed observers, such as Ridley's wine trade journal, agreed that the sale of poor quality wine had ruined the market, noting in 1892 that 'so difficult is it now to dispose of even good sound wines at the moderate figures asked, that the rubbish which caused so much trouble twenty years ago would be practically unsaleable ... even were the shipper prepared to risk his reputation by sending it'. ${ }^{65}$ Wine quality might have once more improved, but consumer confidence had been lost.

Finally, it is clear that the lack of response from Jerez itself in the 1860s and 1870s was not because of the high costs of organisation among the different parties to achieve more 'efficient' institutions, but rather the strength of the shippers who played the two markets: the luxury one that was dependent on preserving the reputation of their name, and the rapidly expanding one for cheap wines. The attitude of shippers therefore was somewhat ambiguous to imitations, which made it difficult for them to argue that sherry was a wine produced only in Jerez de la Frontera. Although shippers attacked the British authorities for allowing wines from other countries to be called sherry, they themselves did little to protect the drink's reputation.

\section{NOTES}

This research has been funded by the Spanish government (PB98-0033, PR2001-0096 and BEC2003-06481). I wish to thank the anonymous referees, Paul Duguid, Enrique Montañés, and the editors for helpful comments. Pre-decimal currency: $£ 1=20$ s (shillings); $1 \mathrm{~s}=12 \mathrm{~d}$ (old pence) $=£ 0.05 \mathrm{p}$ (new pence).

1 The traditional area of sherry production is Jerez de la Frontera, Sanlúcar de Barraneda and Puerto de Santa María, although for brevity I shall refer to this region as that of Jerez.

2 G.B. Wilson, Alcohol and the Nation (London, 1940); B.R. Mitchell, Abstract of British Historical Statistics (Cambridge, 1962), pp.392-5.

3 R. Davis, 'The English Wine Trade in the Eighteenth and Nineteenth Centuries', Annales Cisalpines d'histoire sociale, Vol.3 (1971), pp.87-106; J. Nye, 'The Myth of Free-Trade Britain and Fortress France: Tariffs and Trade in the Nineteenth Century', Journal of Economic History, Vol.51 (1991), pp.23-46.

4 Wines from British possessions, essentially Cape wines, paid half duty.

5 G.R. Porter, The Progress of the Nation (London, 1847 edn.), p.570.

6 J.E. Tennent, Wine, its Use and Taxation (London, 1855), p.28.

7 Ibid., p.152.

8 After 1831, duties on wine imports peaked in 1857, when it represented about ten per cent of revenue from liquor. It then declined during the rest of the century, although the fall was partly offset by growing revenue from licences; Wilson, Alcohol. However, the dynamic gains from trade specialisation after 1860 would have more than made up for the decline in wine duties.

9 Rates changed in 1860, and then again in 1861, but those introduced in 1862 lasted until 1886.

10 A. Briggs, Wine for Sale: Victoria Wine and the Liquor Trade, 1860-1984 (London, 1985), p.37.

11 Hansard, Parliamentary Debates, 10 Feb. 1860, cited in ibid., p.11.

12 French wines were often mixed with Spanish wines, which in turn had been strengthened with alcohol, but most remained under 26 degrees proof (Table 2).

13 A.D. Francis, The Wine Trade (London, 1972), p.300.

14 C. Redding, A History and Description of Modern Wines (London, 1833), p.191. 
15 Ibid., p.322.

16 J. Burnett, Plenty and Want. A Social History of Food in England from 1815 to the Present Day (London, 1989, 3rd edition), chapter 5; and Parliamentary Papers, Report from the Select Committee on Adulteration of Food (1855, viii), First Report (432), pp.1-45. It was claimed in this report that wine adulteration in the United Kingdom was equivalent to 20 per cent of wine imports; ibid., Second Report (480), p.35.

17 M. French and J. Phillips, Cheated not Poisoned? Food Regulation in the United Kingdom, 1875-1938 (Manchester, 2000), pp.36-7. The act allowed local authorities to inspect retail outlets, but not manufacturers. The three Acts of Parliament between 1860 and 1872 had failed to provide an efficient legal basis to combat adulteration of food and drink.

18 Ibid., p.4.

19 Parliamentary Papers, Report from the Select Committee on Adulteration of Food Act (1872) (1872, vi), pp.206 and 213; see note 30.

20 Ridley's Wine and Spirit Review (hereafter Ridley's) (May 1860), p.5.

21 For the area of vines, see especially A. López Estudillo, 'La vid y los viticultores de Jerez, la crisis comercial y el impacto de la filoxera: un campo abierto a la investigación', Revista de Historia de Jerez, No.1 (1992), pp.50-53; J. Simpson, 'La Producción de vinos en Jerez de la Frontera', in P. Martín Aceña and L. Prados de la Escosura (eds), La Nueva Historia Económica en España (Madrid, 1985), p.175; S. Zapata, 'La producción agraria de Extremadura y Andalucía Occidental, 1875-1935' (unpublished Ph.D. thesis, Universidad Complutense de Madrid, 1986).

22 Ridley's, various years. A study in the 1880s estimates that more than half the wines of the region were exported, including virtually all the quality sherry, Archivo del Ministerio de Agricultura, legajo 82.2.

23 Ridley's (Feb. 1860), p.5. In the mid-nineteenth century the minimum age when good sherry was exported was five or six years.

24 Parliamentary Papers, Report from the Select Committee on Wine Duties (1878/79, vol.xiv), p.176 and Ridley's (April 1887), p.166.

25 Parliamentary Papers, Wine Duties, p.169; see also p.119.

26 Ridley's (Sept. 1867), p.2.

27 J. Simpson, Selling to Reluctant Drinkers: The British Wine Market, 1860-1914, in preparation.

28 Ridley's (Sept. 1863), p.16. George Ridley was subsequently given the Cross of the Order of Carlos III in 1870. Ibid. (March 1870), p.4.

29 Quoted in C. Tovey, Wine Revelations (London, 1880).

30 Jerez produced its own version of 'Hamburg Sherry' according to the British Consul's report of 1865: 'During the past year large quantities of wines have been introduced into the district from Malaga and Alicante; but these wines have not proved serviceable or usable, their peculiar, earthy and tarry character being impossible to overcome; as, although mixed with other wines but in small quantities, the unpleasant flavour and "smell" is always distinguishable to a judge of wine.' This did not stop the wines being used, however: 'The low spirituous compounds are made up with molasses, German potato-spirit, and water; to which some colouring matter, and a small quantity of wine are added; much in the same manner that the "Hamburg-sherries" have been manufactured to which of late the London Custom-House has, very properly, refused admission.' Parliamentary Papers, Consular Reports, Cadiz (1865, liii), p.657.

31 N. Faith, Victorian Vineyard: Chateau Loudenne and the Gilbeys (London, 1983), p.12; Ridley's (Jan. 1877), p.3. 'Castle' was the brand name of Gilbey's. Given Gilbey's insistence on quality, it seems highly unlikely that its version was prejudicial to health. However, it created confusion for consumers.

32 Parliamentary Papers, Wine Duties, p.149.

33 T.W. Shaw, Wine, the Vine and the Cellar (London, 2nd edn. 1864), p.217.

34 J. Busby, Journal of a Tour through Some of the Vineyards of Spain and France (Sydney, 1833), pp.13-14; Parliamentary Papers, Report from the Select Committee on Import Duties on Wines (1852, xvii), pp.708-47.

35 Ridley's (July 1884), p.238.

36 Parliamentary Papers, Wine Duties, pp.121, 122, 170 and 266.

37 See especially J. Pan-Montojo, La bodega del mundo: La vid y el vino en España 1800-1936 (Madrid, 1994), pp.103-10.

38 Parliamentary Papers, Wine Duties, p.143.

39 Ibid., pp.26 and 182.

40 Ibid., see especially pp.55 and 162 .

41 Ridley's (Feb. 1888), pp.58, 62 and 70; (Oct. 1888), p.474.

42 Busby, Journal, p.3.

43 J. Jeffs, Sherry (London, 1970), p.193.

44 Ridley's (March 1892), p.165.

45 P. Ponsot, Atlas de historia económica de la baja Andalucía: siglos XVI y XIX (Granada, 1986) gives an increase from slightly under 10 reales ( 2.5 pesetas) to 19 reales. In Cataluña wages increased from 2 pesetas to 2.2 pesetas; R. Garrabou and E. Tello, 'Salario como coste, salario com ingreso: el precio de los jornales 
agrícolas en la Cataluña contemporánea, 1727-1930', in J.M. Martínez Carrión, El nivel de vida en la España rural, siglos XVIII-XX (Alicante, 2002), p.629.

46 For wages, see Simpson, La producción de vinos, pp.180-82. Social unrest is well documented in T. Kaplan, Anarchists of Andalusia, 1868-1903 (Princeton, NJ, 1977) and E. Montañes, Transformación agrícola y conflictividad campesina en Jerez de la Frontera, 1880-1923 (Cádiz, 1997).

47 For Jerez, and the Gremio de Vinateros, see especially Pan-Montojo, La bodega del mundo, p.31 and J. Maldonado, La formación del capitalismo en el marco de Jerez (Madrid, 1999), pp.81-153. For port wine, see especially P. Duguid and T. da Silva Lopes, 'Ambiguous Company: Institutions and Organizations in the Port Wine Trade, 1814-1834', Scandinavian Economic History Review, Vol.XLVII (1999), pp.84-102.

48 Ibid.

49 K.M. Guy, 'Wine, Work and Wealth: Class Relations and Modernization in the Champagne Wine Industry, 1870-1914' (unpublished Ph.D. thesis, University of Wisconsin, 1996).

50 See, for example, the growers' journal, Revista Vinícola Jereza, begun in 1866. Death threats were noted in Ridley's (May 1871), p.7.

51 For González Byass, see P. Férnandez-Pérez, 'Challenging the Loss of an Empire: González \& Byass of Jerez’, Business History, Vol.41 (1999), pp.72-87; Jeffs, Sherry, chapter 6 and E. Montañés, La empresa exportadora del Jerez. Historia Económica de González Byass, 1835-1885 (Cádiz, 2000).

52 Domecq, for example, shipped large quantities of 'light low' wines in 1864 and 1865 which did not carry his brand. Ridley's (Feb. 1867), p.2. Likewise, Gilbey's imported unbranded sherry and white wine from González Byass. For the impact of this cheap wine trade on a shipper's profits, see especially Montañés, $L a$ empresa exportadora.

53 Under pressure from the wine trade in London, this list was finally ended in 1878, Ridley's (Feb. 1878); see also (March 1871) and (Jan. 1874).

54 For example, González Byass auctioned 2,500 butts of old sherry at the end of the nineteenth century because it was 'considered in excess of requirements'. Ridley's (May 1895), p.304.

55 See especially A. Cabral Chamorro, 'Observaciones sobre la regulación y ordenación del mercado del vino de Jerez de la Frontera 1850-1935: los antecedentes del Consejo Regulador de la Denominación de Origen “Jerez-Xérès-Sherry", Agricultura y Sociedad, Vol.44 (1987), p.192.

56 Ibid., pp.193-4.

57 See M. Casson, 'Brands. Economic Ideology and Consumer Society', in G. Jones and N. Morgan (eds.), Adding Value: Brands and Marketing (London, 1994), pp.42-8.

58 Gonzalez Byass \& Co.'s 1878 price list for Cadiz, reproduced in Montañés, La empresa exportadora, p.264. Tio Pepe was introduced at the lower duty of $1 \mathrm{~s}(£ 0.05)$ a gallon. Retail prices calculated from Table 1.

59 G. Harrison, Bristol Cream (London, 1955), p.106 suggests 1882, and Harvey's 1867 price list, reproduced opposite p.115 does not mention Bristol Cream. However, Ridley's in 1880 (12 July, p.209) cites an auction of one of Harvey's customers where 22 dozen cases of 'Dark Gold Sherry', 'Bristol Milk', bottled December 1862, and 23 cases of 'Old Pale Sherry', 'Bristol Cream', also bottled in 1862, were sold. The average price of the Bristol Cream was over a pound a bottle.

60 Ridley's (Sept. 1882), p.275.

61 See Jeffs, Sherry, pp.93-6.

62 Parliamentary Papers, Wine Duties, p.176.

63 Ridley's (Nov. 1898), p.762.

64 Pan-Montojo, La bodega del mundo, p.113.

65 Ridley's (March 1892), p.163. 